CLINICAL STUDY

\title{
Minimal changes in environmental temperature result in a significant increase in energy expenditure and changes in the hormonal homeostasis in healthy adults
}

\author{
Francesco S Celi ${ }^{1}$, Robert J Brychta ${ }^{1}$, Joyce D Linderman ${ }^{1}$, Peter W Butler ${ }^{1,2}$, Anna Teresa Alberobello ${ }^{1}$, \\ Sheila Smith ${ }^{1}$, Amber B Courville ${ }^{3}$, Edwin W Lai ${ }^{2}$, Rene Costello ${ }^{3}$, Monica C Skarulis ${ }^{1}$, Gyorgy Csako ${ }^{3}$, \\ Alan Remaley ${ }^{3}$, Karel Pacak ${ }^{2}$ and Kong Y Chen ${ }^{1}$ \\ ${ }^{1}$ Clinical Endocrinology Branch, National Institute of Diabetes and Digestive and Kidney Diseases, ${ }^{2}$ Reproductive and Adult Endocrinology Branch, Eunice \\ Kennedy Shriver National Institute of Child Health and Human Development and ${ }^{3}$ Department of Laboratory Medicine, Clinical Center, National Institutes \\ of Health, Building 10, CRC, RM 6-3940, 10 Center Drive, MSC 1613, Bethesda, Maryland 20892-1613, USA
}

(Correspondence should be addressed to F S Celi; Email: fc93a@nih.gov)

\begin{abstract}
Objective: Resting energy expenditure (EE) is a major contributor to the total EE and thus plays an important role in body weight regulation. Adaptive thermogenesis is a major component of $\mathrm{EE}$ in rodents, but little is known on the effects of exposure of humans to mild and sustainable reduction in environmental temperature.

Design: To characterize the dynamic changes in continuously measured resting EE, substrate utilization, and hormonal axes simultaneously in response to mild reduction in environmental temperature, we performed a cross-over intervention.

Methods: Twenty-five volunteers underwent two 12-h recordings of EE in whole room indirect calorimeters at 24 and $19{ }^{\circ} \mathrm{C}$ with simultaneous measurement of spontaneous movements and hormonal axes.

Results: Exposure to $19{ }^{\circ} \mathrm{C}$ resulted in an increase in plasma and urine norepinephrine levels $(P<0.0001)$, and a $5.96 \%(P<0.001)$ increase in EE without significant changes in spontaneous physical activity. Exposure to the lower temperature resulted in a significant increase in free fatty acid levels $(P<0.01)$, fasting insulin levels $(P<0.05)$, and a marginal decrease in postprandial glucose levels. A small but significant $(P<0.002)$ increase in serum free thyroxine and urinary free cortisol $(P<0.05)$ was observed at $19{ }^{\circ} \mathrm{C}$.

Conclusions: Our observations indicate that exposure to $19{ }^{\circ} \mathrm{C}$, a mild and tolerable cold temperature, results in a predictable increase in EE driven by a sustained rise in catecholamine and the activation of counter-regulatory mechanisms.
\end{abstract}

European Journal of Endocrinology 163 863-872

\section{Introduction}

Obesity, which is the result of a sustained imbalance between energy intake and energy expenditure (EE), has reached epidemic proportions. As a result, obesityrelated complications contribute substantially to mortality and healthcare costs (1). Interestingly, even small but prolonged changes in the energy balance equation (energy gap), as low as $100 \mathrm{kcal} /$ day, may play a significant role in the gradual weight gain observed in the adult population (2). Most obesity-directed interventions, pharmacological and behavioral, are aimed at reducing energy intake. No intervention, except increased physical activity, is successful at increasing EE safely and effectively. Besides physical activity (voluntary, spontaneous, and shivering), the other components of total EE are the thermic effect of food and resting EE (3). In humans, resting EE accounts for $65-85 \%$ of total EE and is mainly determined by body size and composition, but it can also be influenced by pathological states, such as hypo- or hyper-thyroidism (4), fever, and drugs (5).

Exposure to cold temperature $\left(16{ }^{\circ} \mathrm{C}\right)$ results in a predictable increase in resting EE (6) (non-shivering thermogenesis), which may be partly explained by an activation of brown adipose tissue (7-9). However, such a level of cold exposure is not sustainable over a long period of time. Furthermore, to our knowledge, no study aimed at characterizing the changes in EE upon temperature manipulation within the range observed in climate-controlled buildings has been performed. Interestingly, the recent trend in regulating indoor climates has been proposed as a significant contributor to the increase in obesity prevalence (10). In this study, 
we have accurately characterized the changes in EE, substrate utilization, heart rate variability, temperature, and hormonal homeostasis in healthy volunteers of both sexes exposed to $19{ }^{\circ} \mathrm{C}$, well within the range of tolerability.

\section{Materials and methods}

\section{Participants and study design}

The study was approved by the NIDDK-NIAMS IRB and conducted at the NIH Clinical Center in Bethesda, MD, USA. The protocol was designed as a randomized, single blind, cross-over intervention study (ClinicalTrials.gov identifier number NCT00521729). Inclusion criteria for the enrollment in the study were an age range of 18-60 years and body mass index (BMI) $20-27 \mathrm{~kg} / \mathrm{m}^{2}$. Exclusion criteria were thyroid disease (by history or TSH $<0.4$ or $>5.0 \mathrm{mIU} / \mathrm{l}$ at screening); hypertension (by history or blood pressure values $>140 / 90 \mathrm{mmHg}$ ) or cardiovascular disease; pregnancy or use of hormonal contraception; diabetes mellitus; serum cholesterol $\geq 240 \mathrm{mg} / \mathrm{dl}$; and/or serum triglycerides $\geq 220 \mathrm{mg} / \mathrm{dl}$. Female participants were studied in the early follicular phase of the menstrual cycle (days 2-10). After enrollment, the study volunteers were admitted to the Metabolic Clinical Research Unit, and after a 2-day equilibration diet (see below), they were randomly assigned to a 12-h stay in a whole room indirect calorimeter (respiration chamber) at either $24{ }^{\circ} \mathrm{C}$ $\left(75^{\circ} \mathrm{F}\right)$ or $19^{\circ} \mathrm{C}\left(68^{\circ} \mathrm{F}\right)$. After a 36 -h recovery period, the volunteers repeated the 12 -h stay at the second study temperature (Fig. 1A). Two days prior to testing and throughout the duration of the study, the volunteers received a caffeine-free weight maintenance diet providing $50 \%$ carbohydrate, $20 \%$ protein, and $30 \%$ fat. Resting energy requirements for the equilibration diet were calculated from the subject's height, weight, and age using the Mifflin-St Jeor equation (11). An activity factor associated with the subjects' selfreported physical activity was used to calculate their total daily energy needs (12). The day prior to the respiration chamber recording, the study volunteers finished their dinner by $1900 \mathrm{~h}$, i.e. $12 \mathrm{~h}$ before the study. After a 6 -h stay in the respiration chamber, the volunteers received one standard liquid meal (Boost Plus, Nestle Healthcare Nutrition, Inc., Vevey, Switzerland) representing $30 \%$ of their calculated energy needs as part of the equilibration diet. After the completion of the 12-h chamber recording, the volunteers were offered a meal containing the remaining $70 \%$ calorie content of the estimated daily energy needs. Throughout the recordings, the volunteers wore standard clothing (hospital scrubs), and no blanket was provided. The volunteers were asked to limit their physical activity to a minimum and were encouraged to watch TV or to use a computer while sitting on a
A Study protocol, overview

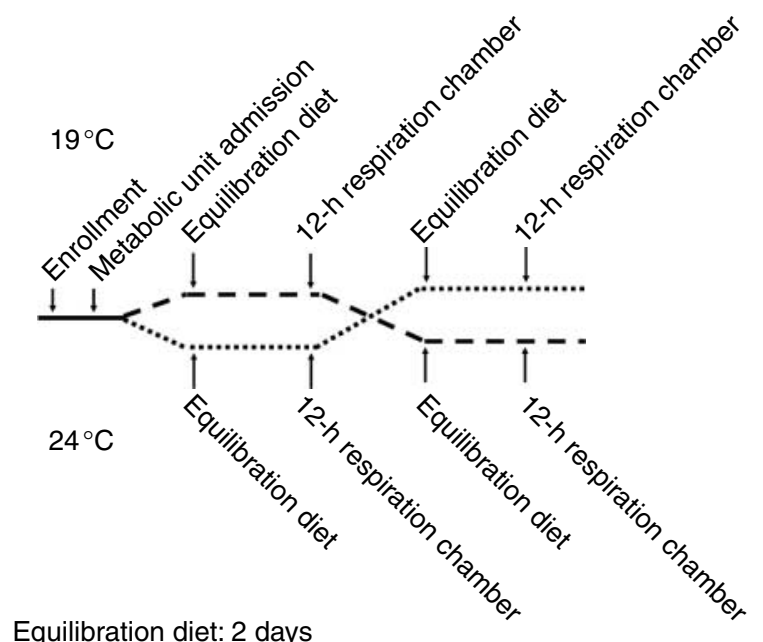

Equilibration diet: 2 days

B

12-h respiration chamber stay, procedures and specimens sampling protocol

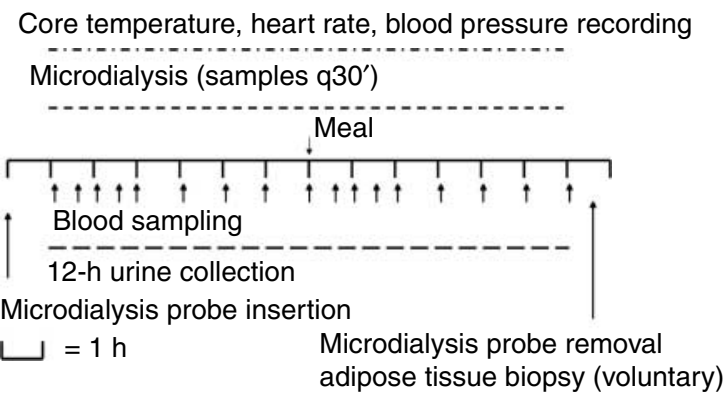

Figure 1 (A) Study protocol overview. The study was designed as a randomized, single blind, cross-over intervention. After enrollment, the volunteers received a weight maintenance diet for 2 days before undergoing 12-h respiration chamber and hormonal axes recording. After $36 \mathrm{~h}$ of recovery, the study volunteers underwent the same procedure at the second experimental temperature (see text for details). (B) Blood samples collection and procedures during a 12-h respiration chamber stay. Blood sampling was performed through an airtight sampling port every hour except during the first $2 \mathrm{~h}$ of the recording and the first $2 \mathrm{~h}$ after the meal when the sampling was performed every $30 \mathrm{~min}$.

recliner or staying in bed. Blood samples were collected at $-15,0,30,60,90,120,180,240,300,360,390$, $420,450,480,540,600,660$, and $720 \mathrm{~min}$ via one of the airtight sampling ports while the volunteer was sitting in the recliner. Samples for microdialysis $(15 \mu \mathrm{l})$ were collected at baseline and every $30 \mathrm{~min}$ throughout the recordings (Fig. 1B); microdialysis vials were passed via one of the airtight sampling ports and stored at $-20{ }^{\circ} \mathrm{C}$ until processed.

\section{Respiration chamber}

Each study volunteer underwent continuous recordings of $\mathrm{EE}$ and respiratory quotient in a whole room indirect calorimeter. A similar calorimeter was described 
previously $(13,14)$, which can be operated at any stable

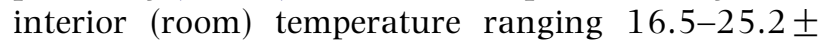
$0.5^{\circ} \mathrm{C}$ and at a relative humidity of $35-55 \%$. All temperature, humidity, and barometric pressure were continuously measured (Optica, GE Sensing, Billerica, MA, USA). Airtight sampling ports and a four-way air-locking food and specimen passage were designed to allow blood draws and specimen retrievals with minimal disturbance to the chamber environment. The accuracy and precision of the respiration chambers were evaluated initially using a series of propane calibration tests at 19 and $24{ }^{\circ} \mathrm{C}$. The results of the tests demonstrated no significant difference in the accuracy of the $\mathrm{VO}_{2}$ and $\mathrm{VCO}_{2}$ measurements between 19 and $24{ }^{\circ} \mathrm{C}$ when the temperature was maintained within $0.2{ }^{\circ} \mathrm{C}$ of the set-point temperature. Each recording started at $0800 \mathrm{~h}$ and ended at 2000 h. Although the chambers have a small window exposed to the south, most of the lighting was provided by fluorescent bulbs.

\section{Weight, height, and body composition}

Each volunteer was weighed daily using a digital balance (Scale-Tronix 5702, Carol Stream, IL, USA) under fasting conditions. Height was measured using a stadiometer (Seca 242, Hanover, MD, USA). Body composition was recorded by a dual-energy X-ray absorptiometry scanner (Lunar iDXA, GE Healthcare, Madison, WI, USA) and analyzed with proprietary software (15).

\section{Physiological monitoring}

Vital signs Blood pressure and heart rate values were recorded in the morning of the study upon awakening and immediately after the completion of the respiration chamber stay.

Heart rate variability A Holter monitor (Del MarReynolds, Irvine, CA, USA) was used to record ECG waveform data throughout each study. The inter-beat interval data were analyzed in a custom program created in Matlab (The Mathworks, Natick, MA, USA). Heart rate variability determination was performed using established methods (16). Thirty minute segments overlapping by $50 \%$ were used to compute the power in the very low frequency, low frequency, and high frequency bands, representing autonomic influence on the heart via hormonal regulation, the sympathetic system, and the parasympathetic system respectively (17).

Core body and skin temperatures Core body and skin temperatures were measured continuously using ingestible capsules and dermal patches (Philips Respironics, Bend, OR, USA). The dermal patches were placed on the posterior aspect of the neck, abdomen ( 1 inch above the navel), and dominant thigh.

Activity monitors Actical accelerometers (Philips Respironics) worn on the wrist, ankle, and hip were used to record the subjects' physical activity every $15 \mathrm{~s}$.

Data processing Data recorded by the physiological monitors (heart rate, core body and skin temperatures), physical activity monitors, and respiration chamber were processed in identical fashion for the 24 and $19{ }^{\circ} \mathrm{C}$ studies. The first hour of the recording was excluded from the analysis to allow for equilibration of the respiration chamber equipment and for the volunteer to be acclimated to the chamber environment. The last hour of the recording was also excluded from the analysis to prevent contamination of the data from anticipatory activity. The intervening $10-\mathrm{h}$ recording from minute 61 to 660 was analyzed. The hours preceding and following the meal were excluded from the pre- and postprandial analyses, only to prevent feeding-related anticipation or activity from confounding the data.

\section{Microdialysis}

Microdialysis of subcutaneous adipose tissue was performed using a CMA 60 (CMA Microdialysis, Stockholm, Sweden) catheter with a flow rate of $0.5 \mu \mathrm{l} / \mathrm{min}$ using Ringer's solution. The study volunteers were instructed in changing the vials every $30 \mathrm{~min}$. Glucose and glycerol were measured by a microanalyzer (CMA Microdialysis).

\section{Subcutaneous adipose tissue biopsy}

Seven volunteers consented for subcutaneous adipose tissue biopsy from the periumbilical area within $30 \mathrm{~min}$ of the completion of each respiration chamber recording.

\section{Laboratory assessment}

Plasma specimens collected in chilled tubes were separated within $30 \mathrm{~min}$, whereas serum specimens were separated within $1 \mathrm{~h}$ of collection. For the measurement of urine analytes (urea, myoglobin, cortisol, and catecholamines), 12-h specimens were collected by splitting them in non-preservative and preservative (acetic acid) containers as appropriate for the test. Urinary myoglobin and urinary free cortisol concentrations were measured at the Mayo Medical Laboratories (Rochester, MN, USA). Plasma catecholamine concentrations were determined in the laboratories of the Reproductive Biology and Medicine Branch of NICHD (18), whereas all other tests were performed in the NIH Clinical Center Department of Laboratory Medicine. 


\section{Real-time PCR}

Total RNA was extracted from the subcutaneous adipose tissue samples using the RNAzol method and converted to cDNA using a reverse transcriptase kit from Marligen (Ijamsville, MD, USA). The cDNA was then amplified in a TaqMan 7000 real-time PCR apparatus using cyclophillin, UCP1, PRDM16, PGC1 (PPARGC1A), and D2 TaqMan gene expression assays (Applied Biosystems, Foster City, CA, USA).

\section{Statistical analysis}

Statistical analysis was performed using Prism 5 (GraphPad, La Jolla, CA, USA) using two-tailed paired t-test. Non-parametric data were analyzed using Wilcoxon signed rank sum test. Where indicated, data were log transformed. The area under the curve (AUC) was calculated using the trapezoidal rule. Results are expressed as mean \pm 1 S.D.; an $\alpha$ error of 0.05 was considered the threshold for statistical significance. A power calculation was performed $a$ priori based on the primary outcome of EE. Assuming a delta value of $7 \%$ in EE for a $6{ }^{\circ} \mathrm{C}$ difference in environmental temperature (19), a sample size of ten subjects from each gender would provide an $80 \%$ statistical power at a significance of $P<0.05$.

\section{Results}

\section{Study volunteers' characteristics}

Twenty-five eligible individuals (Table 1) completed the study (Fig. 2).

\section{Physiological parameters}

A summary of the physiological recordings is reported in Table 2.

Table 1 Subject characteristics (mean \pm S.D).

\begin{tabular}{|c|c|c|c|}
\hline & $\begin{array}{l}\text { Male } \\
(n=15)\end{array}$ & $\begin{array}{l}\text { Female } \\
(n=10)\end{array}$ & $\begin{array}{l}\text { Total } \\
(n=25)\end{array}$ \\
\hline Height (cm) & $174.7 \pm 7.6$ & $165.8 \pm 6.3$ & $171.1 \pm 8.3$ \\
\hline Weight (kg) & $73.1+9.6$ & $61.0+5.3$ & $68.2+10.0$ \\
\hline $\operatorname{BMI}\left(\mathrm{kg} / \mathrm{m}^{2}\right)$ & $23.9 \pm 2.2$ & $22.2 \pm 1.9$ & $23.3 \pm 2.2$ \\
\hline Age (years) & $26.1 \pm 5.8$ & $32.3 \pm 10.6$ & $28.6 \pm 8.5$ \\
\hline Body fat $(\%)^{a}$ & $19.7 \pm 6.2$ & $26.4 \pm 3.5$ & $22.7 \pm 6.1$ \\
\hline 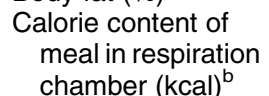 & $837 \pm 163$ & $630 \pm 78$ & $754 \pm 169$ \\
\hline Ethnicity & $\begin{array}{l}8 \text { Caucasian } \\
2 \text { Black } \\
4 \text { Asian } \\
1 \text { Hispanic }\end{array}$ & $\begin{array}{l}6 \text { Caucasian } \\
3 \text { Black } \\
1 \text { Asian }\end{array}$ & $\begin{array}{l}14 \text { Caucasian } \\
5 \text { Black } \\
5 \text { Asian } \\
1 \text { Hispanic }\end{array}$ \\
\hline
\end{tabular}

${ }^{a} n=22$ (ten females)

${ }^{\mathrm{b}}$ Thirty-percent of calculated daily energy needs.

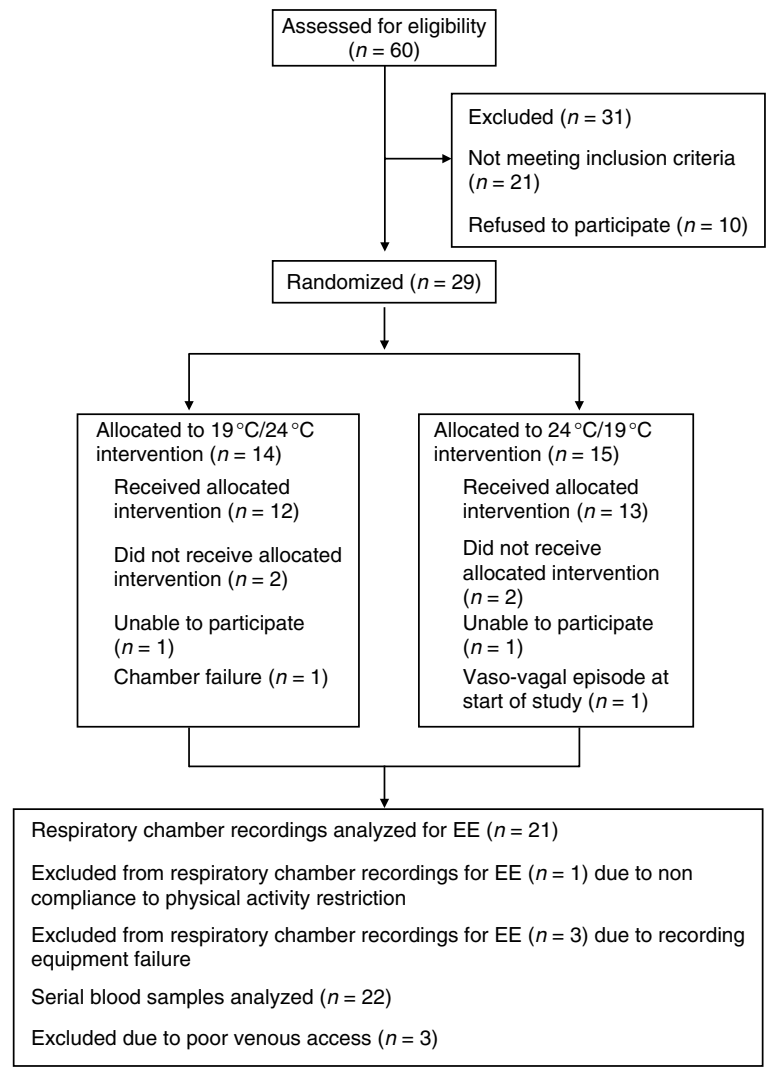

Figure 2 CONSORT chart. Study volunteers screening, accrual, temperature sequence allocation, and completion rate.

Respiration chamber Exposure to $19{ }^{\circ} \mathrm{C}$ resulted in an increase in EE in 18 of 21 subjects (Fig. 3), with a group mean of $5.96 \%(P<0.001)$ and a trend toward a decrease in preprandial respiratory quotient $(P=0.09)$. At $19^{\circ} \mathrm{C}$, the increase in EE was observed both pre- and postprandially (Fig. 4 and Table 2). No differences were observed between the sexes.

Physical activity No difference in the physical activity was observed in the subjects at the two temperature exposures (Table 2).

Core body and skin temperatures There was no significant change in the core body temperature, but skin temperatures at the neck, abdomen, and thigh were reduced at $19{ }^{\circ} \mathrm{C}$ (all $P<0.001$ ). The core body and thigh temperatures demonstrated a significant increase during the postprandial period at 24 and $19{ }^{\circ} \mathrm{C}$ (both $P<0.01$ ).

Heart rate and heart rate variability Heart rate was significantly reduced at $19{ }^{\circ} \mathrm{C}(P=0.004)$. The magnitude of all three heart rate variability components significantly increased at $19{ }^{\circ} \mathrm{C}(P<0.001)$. 


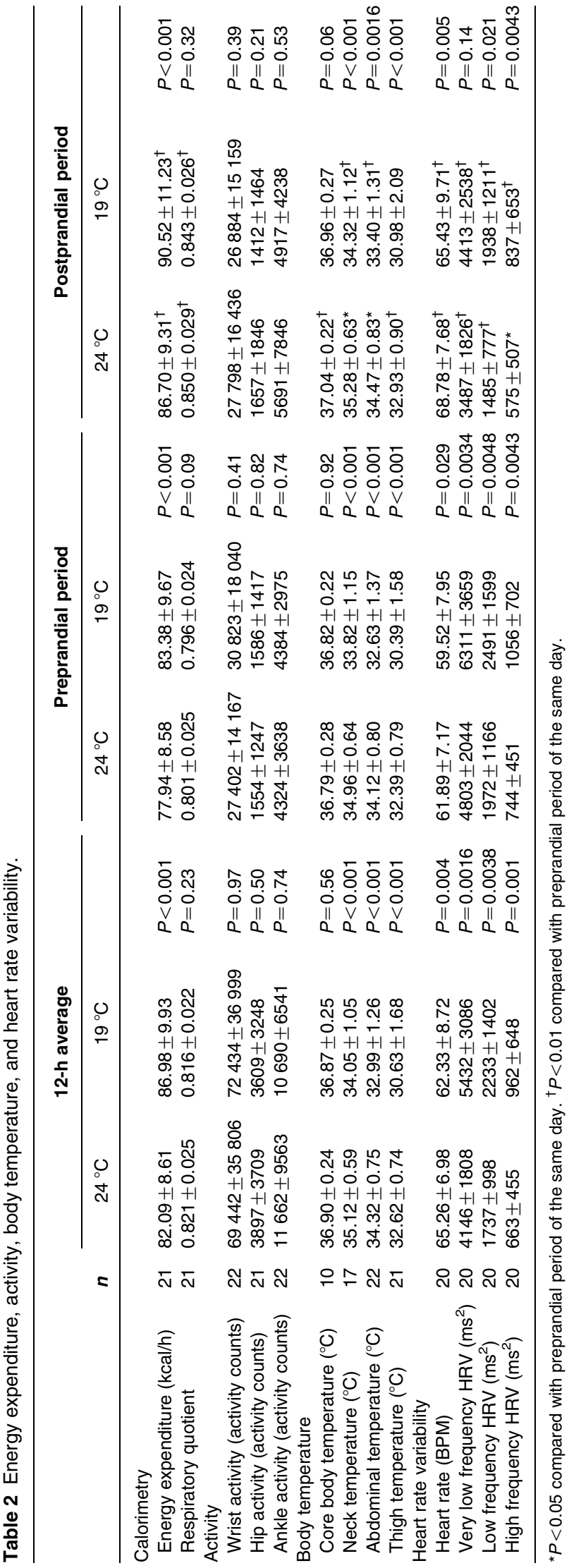

Blood pressure No significant difference was observed at baseline in either systolic $\left(24^{\circ} \mathrm{C}\right.$ : $116.1 \pm 11.8$ vs $\left.19{ }^{\circ} \mathrm{C}: 118.3 \pm 10.0 \mathrm{mmHg}, P=\mathrm{NS}\right)$ or diastolic $\left(24^{\circ} \mathrm{C}\right.$ : $66.8 \pm 7.3$ vs $19^{\circ} \mathrm{C}: 68.8 \pm 7.9 \mathrm{mmHg}, P=\mathrm{NS}$ ) blood pressure. Conversely, at $19{ }^{\circ} \mathrm{C}$ upon completion of the study, both systolic $\left(24^{\circ} \mathrm{C}\right.$ : $125.8 \pm 12.7$ vs $19^{\circ} \mathrm{C}$ : $130.6 \pm 13.5 \mathrm{mmHg}, \quad P<0.05)$ and diastolic $\left(24^{\circ} \mathrm{C}\right.$ : $70.4 \pm 6.7$ vs $19{ }^{\circ} \mathrm{C}: \quad 76.4 \pm 11.9 \mathrm{mmHg}, \quad P<0.02$ ) blood pressure values were significantly increased.

\section{Laboratory data}

The laboratory data obtained are reported in Table 3.

Catecholamines While baseline plasma norepinephrine levels were similar between the two temperature exposures, a significant increase in the AUC was observed at $19{ }^{\circ} \mathrm{C}(P<0.0001$; Fig. 4). Concordantly, plasma dihydroxyphenylglycine (DHPG) and 3,4-dihydroxyphenylacetic acid (DOPAC), and 12-h urinary catecholamine showed significant increases (all $P \leq 0.05)$. The observed changes were similar in men and women.

Glucocorticoid axis While no significant changes were observed in both plasma ACTH and serum cortisol AUCs, a small but significant increase in urinary free cortisol was observed at $19{ }^{\circ} \mathrm{C}(P<0.05)$. When the analysis was performed according to the gender, a small but significant increase in serum cortisol AUC $(P<0.04)$ was observed in males but not in females. Conversely, the increase in urinary free cortisol excretion at $19^{\circ} \mathrm{C}$ was significant in females $(P<0.02)$, but not in males.

Thyroid hormones axis Compared with exposure to $24^{\circ} \mathrm{C}$, exposure to $19^{\circ} \mathrm{C}$ resulted in small, nonsignificant increases in total triiodothyronine $\left(\mathrm{T}_{3}\right)$ and TSH AUCs and a significant increase in serum free thyroxine $\left(\mathrm{T}_{4} ; P=0.03\right)$. When the analysis was performed according to the gender, a small but significant increase in serum $\mathrm{T}_{3}$ AUC was observed in males $(P<0.05)$ but not in females. Similarly, while the change in free $\mathrm{T}_{4}$ was highly significant in males $(P<0.002)$, no significant change was observed in females.

Glucose and insulin While no statistical difference was observed in the 12-h AUCs for plasma glucose and the analysis was limited to $3 \mathrm{~h}$ following the meal (time 360-540 min), a significant reduction in the AUC was observed at $19{ }^{\circ} \mathrm{C}(P<0.05)$. Conversely, although no significant change was observed in postprandial insulin AUC, exposure to $19{ }^{\circ} \mathrm{C}$ resulted in a small but significant increase in fasting (time -15 to $300 \mathrm{~min}$ ) insulin AUC $(P=0.04)$ without differences between the sexes. 


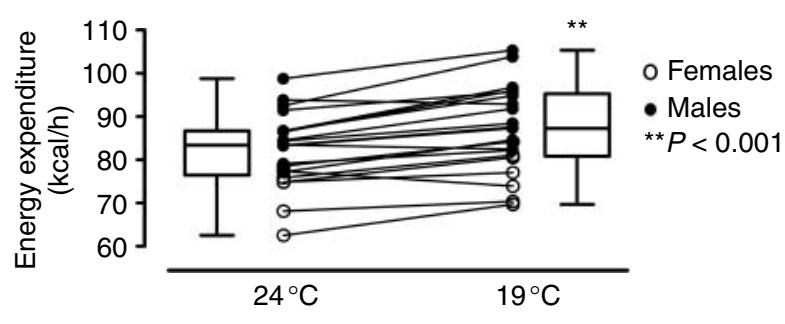

Figure 3 Mean energy expenditure rate in 21 participants over $12 \mathrm{~h}$ spent at $24^{\circ} \mathrm{C}$ (left) and $19^{\circ} \mathrm{C}$ (right). Data are presented as individual recordings and as box-whisker plots for all the 21 participants, 14 males (filled circles) and 7 females (open circles).

Free fatty acids and $\boldsymbol{\beta}$-hydroxybutyrate Exposure to $19^{\circ} \mathrm{C}$ resulted in a significant increase in free fatty acids $(P<0.01)$ and a non-significant increase in $\beta$-hydroxybutyrate AUCs without differences between the sexes.

Real-time PCR analysis and microdialysis of subcutaneous adipose tissue No transcript was observed for UCP1 and D2, and a weak signal was observed for PRDM16 and PGC1. No significant change was observed in the expression levels of these two genes (data not shown). A trend toward an increase in the glycerol AUC was observed in the microdialysate $(P=0.07)$ at $19{ }^{\circ} \mathrm{C}$. Conversely, a non-significant reduction in the glucose AUC was observed in the same group $(P=0.07)$, without differences between the sexes.

\section{Discussion}

The primary aim of this study was to quantify the dynamic changes in $\mathrm{EE}$ and to investigate their associations with changes in hormonal axes, substrate utilization, and autonomic nervous system parameters in healthy subjects of both sexes exposed to a sustainable reduction in environmental temperature. We thus targeted whole-body adaptive thermogenesis, irrespective of the anatomical or tissue distribution. The two experimental conditions (19 and $24^{\circ} \mathrm{C}$ ) were chosen because they are tolerable and closely represent the range of temperatures in climate-controlled buildings and homes. To accurately measure the changes in hormonal homeostasis and substrate utilization, we performed multiple blood sampling concomitant to the EE measurement. We further explored the acute effects of a standard meal on these physiological parameters.

Our data demonstrate that a $5{ }^{\circ} \mathrm{C}$ reduction in the environmental temperature resulted in a consistent increase of about $6 \%$ in $\mathrm{EE}$ without differences between the sexes. The observed changes are due to an increase in non-shivering thermogenesis without any measurable increase in spontaneous physical activity. The relative magnitude of this increase in EE was generally similar to that measured by others (20) upon exposure to colder temperatures for longer periods.

Not surprisingly, the exposure to $19{ }^{\circ} \mathrm{C}$ resulted in a decrease in skin temperature due to superficial vasoconstriction, which was consistent with previous findings (20). Contrary to earlier experiments (20) performed at a colder temperature $\left(16^{\circ} \mathrm{C}\right)$, we did not observe changes in the core body temperature. A postmeal increase in temperature, indicating a measurable thermic effect of food, was present in both the abdomen and the neck regions at 24 and $19^{\circ} \mathrm{C}$. However, this response was not observed at $19{ }^{\circ} \mathrm{C}$ in either the thigh or the core body temperatures, suggesting that the thermic effect of food is somewhat blunted upon exposure to $19{ }^{\circ} \mathrm{C}$.

We postulate that the increase in sympathetic nervous system activity, as evidenced by the relative elevation of plasma and urinary catecholamine and by the increase in the low frequency heart rate variability, is a major effector for the increase in $\mathrm{EE}$ in response to $19{ }^{\circ} \mathrm{C}$. The dynamic changes in plasma concentrations of DOPAC and DHPG mirrored that of norepinephrine, indicating that the overall catecholamine turnover was up-regulated. Consistent with previous findings (21), the observed reduction in the heart rate and the increase in blood pressure are most likely secondary to peripheral vasoconstriction.
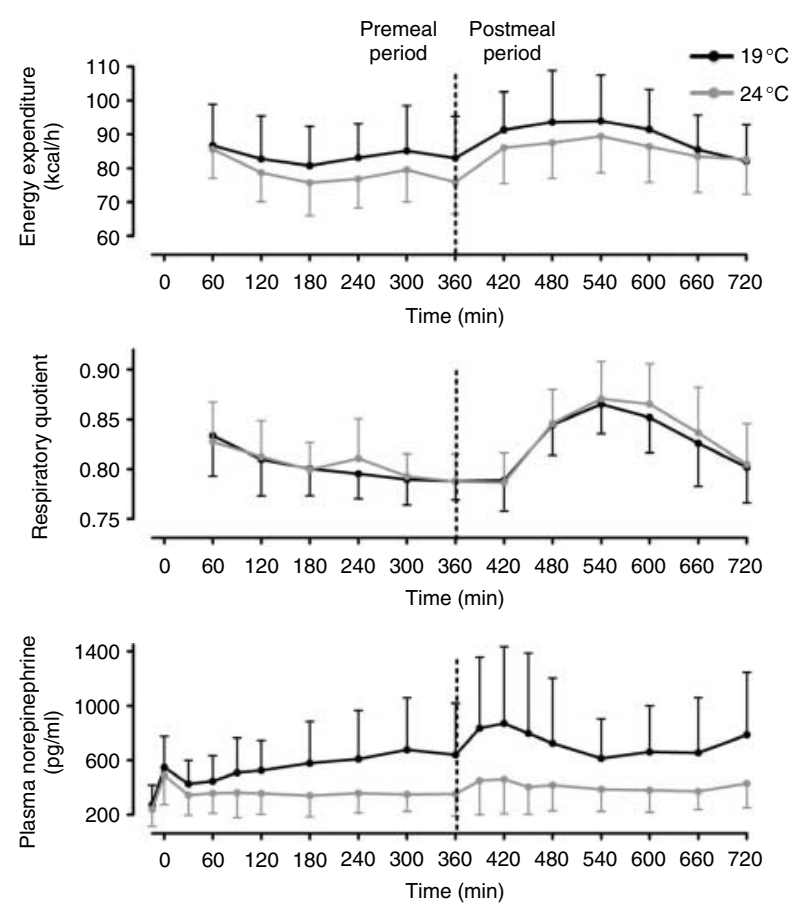

Figure 4 Mean and S.D. of 21 participants for energy expenditure (top panel), respiratory quotient (middle panel), and plasma norepinephrine levels (bottom panel) at $24^{\circ} \mathrm{C}$ (gray line) and $19^{\circ} \mathrm{C}$ (black line) over the 12-h time course of the study. The dotted line indicates meal consumption at $360 \mathrm{~min}$. 
Table 3 Laboratory data.

\begin{tabular}{|c|c|c|c|}
\hline & $24^{\circ} \mathrm{C}$ & $19^{\circ} \mathrm{C}$ & $\boldsymbol{P}$ \\
\hline \multicolumn{4}{|l|}{ Catecholamines } \\
\hline Plasma norepinephrine AUC $\left(\times 10^{5} \mathrm{pg} \mathrm{min} / \mathrm{ml}\right)$ & $2.74 \pm 1.11$ & $4.68 \pm 2.27$ & $<0.0001$ \\
\hline Plasma norepinephrine $420^{\prime}(\mathrm{pg} / \mathrm{ml})$ & $464.0 \pm 264.7$ & $895.7 \pm 565.9$ & $<0.001$ \\
\hline Urine epinephrine $(\mu \mathrm{g} / 12 \mathrm{~h})$ & $5.10 \pm 2.415$ & $6.41 \pm 3.636$ & 0.05 \\
\hline Urine norepinephrine $(\mu \mathrm{g} / 12 \mathrm{~h})$ & $20.70 \pm 8.659$ & $29.44 \pm 11.29$ & $<0.001$ \\
\hline Urinary DOPAC $(\mu \mathrm{g} / 12 \mathrm{~h})$ & $118.1 \pm 47.80$ & $136.3 \pm 42.08$ & 0.03 \\
\hline DOPAC AUC (×106 pg min/ml) & $0.97 \pm 0.45$ & $1.14 \pm 0.69$ & 0.04 \\
\hline DHPG AUC ( $\left.\times 10^{5} \mathrm{pg} \mathrm{min} / \mathrm{ml}\right)$ & $8.12 \pm 3.59$ & $9.35 \pm 4.25$ & $<0.01$ \\
\hline \multicolumn{4}{|l|}{ Glucocorticoid axis } \\
\hline ACTH AUC $\left(\times 10^{4} \mathrm{pg} \mathrm{min} / \mathrm{ml}\right)$ & $1.25 \pm 0.42$ & $1.29 \pm 0.54$ & 0.49 \\
\hline Serum cortisol AUC $\left(\times 10^{3} \mu \mathrm{g} \mathrm{min} / \mathrm{dl}\right)$ & $6.69 \pm 1.26$ & $7.03 \pm 1.26$ & 0.21 \\
\hline Urinary cortisol ( $\mu \mathrm{g} / \mathrm{g}$ creatinine) & $28.5 \pm 17.4$ & $38.5 \pm 33.2$ & $<0.02$ \\
\hline \multicolumn{4}{|l|}{ Thyroid hormone axis } \\
\hline TSH AUC $\left(\times 10^{3} \mu \mathrm{UI} \mathrm{min} / \mathrm{ml}\right)$ & $0.98 \pm 0.57$ & $1.04 \pm 0.53$ & 0.22 \\
\hline $\mathrm{T}_{3} \mathrm{AUC}\left(\times 10^{4} \mathrm{ng} \mathrm{min} / \mathrm{dl}\right)$ & $7.02 \pm 1.14$ & $7.22 \pm 1.31$ & 0.07 \\
\hline Free $\mathrm{T}_{4}$ AUC $\left(\times 10^{3} \mathrm{ng} \mathrm{min} / \mathrm{dl}\right)$ & $0.98 \pm 0.13$ & $1.02 \pm 0.15$ & 0.02 \\
\hline \multicolumn{4}{|l|}{ Serum glucose and insulin } \\
\hline Glucose AUC $\left(\times 10^{3} \mathrm{mg} \mathrm{min} / \mathrm{dl}\right)$ & $65.90 \pm 4.32$ & $65.03 \pm 4.20$ & 0.29 \\
\hline Fasting glucose $\mathrm{AUC}\left(-15^{\prime}\right.$ to $\left.300^{\prime}\right)\left(\times 10^{3} \mathrm{mg} \mathrm{min} / \mathrm{dl}\right)$ & $26.63 \pm 1.95$ & $26.62 \pm 2.04$ & 0.99 \\
\hline Postmeal glucose AUC $\left(360^{\prime}-540^{\prime}\right)\left(\times 10^{3} \mathrm{mg} \mathrm{min} / \mathrm{dl}\right)$ & $19.71 \pm 2.55$ & $18.69 \pm 2.61$ & 0.04 \\
\hline Insulin AUC $\left(\times 10^{3} \mathrm{mIU} \mathrm{min} / \mathrm{ml}\right)$ & $8.53 \pm 3.44$ & $10.77 \pm 6.34$ & 0.07 \\
\hline Fasting insulin AUC $\left(-15^{\prime}\right.$ to $\left.300^{\prime}\right)\left(\times 10^{3} \mathrm{mIU} \mathrm{min} / \mathrm{ml}\right)$ & $0.65 \pm 0.86$ & $0.83 \pm 0.98$ & 0.04 \\
\hline Postmeal insulin AUC $\left(360^{\prime}-540^{\prime}\right)\left(\times 10^{3} \mathrm{mlU} \mathrm{min} / \mathrm{ml}\right)$ & $5.78 \pm 2.19$ & $7.39 \pm 5.11$ & 0.13 \\
\hline \multicolumn{4}{|l|}{ Microdialysis of subcutaneous adipose tissue } \\
\hline Glycerol AUC $\left(\times 10^{5} \mu \mathrm{mol} \mathrm{min} / \mathrm{ml}\right)$ & $1.12 \pm 0.50$ & $1.35 \pm 0.62$ & 0.07 \\
\hline Glucose AUC $\left(\times 10^{3} \mathrm{mmol} \mathrm{min} / \mathrm{ml}\right)$ & $2.84 \pm 0.60$ & $2.56 \pm 0.60$ & 0.07 \\
\hline \multicolumn{4}{|l|}{ Other measurements } \\
\hline Free fatty acids AUC $\left(\times 10^{5} \mu \mathrm{Eq} \min / \mathrm{l}\right)$ & $2.88 \pm 0.93$ & $3.24 \pm 1.14$ & $<0.01$ \\
\hline$\beta$-Hydroxybutyrate AUC $\left(\times 10^{4} \mu \mathrm{mol} \mathrm{min} / \mathrm{l}\right)$ & $7.70 \pm 4.27$ & $9.58 \pm 6.95$ & 0.50 \\
\hline Creatinine kinase AUC $\left(\times 10^{5} \mathrm{U} \mathrm{min} / \mathrm{l}\right)$ & $1.02 \pm 0.77$ & $1.08 \pm 0.82$ & 0.62 \\
\hline Urinary myoglobin & Not detected & Not detected & \\
\hline
\end{tabular}

Contrary to previous observations $(7,20)$, we did not observe any substantial difference in substrate utilization, although we observed a trend toward a reduction in fasting respiratory quotient (RQ) at $19{ }^{\circ} \mathrm{C}$. This discrepancy could be explained by differences in experimental conditions, since the lower temperature was milder in this study. The increase in plasma free fatty acids (FFA) is consistent with catecholaminestimulated lipolysis. The marginal increase in glycerol levels in the subcutaneous adipose tissue further supports this explanation.

The effects of catecholamines on glucose metabolism are more complex. The increase in fasting insulin observed at $19{ }^{\circ} \mathrm{C}$ is likely secondary to catecholaminemediated hepatic gluconeogenesis (22); however, it did not extend into the postprandial period and the glucose AUC was lower during this part of the study. Furthermore, the raise in FFA likely contributes to the state of relative insulin resistance observed during fasting. Taken together, these findings can be interpreted as a state of relative insulin resistance and catecholaminestimulated hepatic gluconeogenesis, with an overall increase in total consumption of metabolic fuels. The marginal decrease in glucose levels in the subcutaneous adipose tissue further strengthens this explanation.

At $19^{\circ} \mathrm{C}$, we also observed an increase in free $\mathrm{T}_{4}$ (and serum $\mathrm{T}_{3}$ in men), consistent with a shift toward the activation of the pituitary-thyroid axis. Alternatively, one could speculate that the increase in free $\mathrm{T}_{4}$ (as measured by analog assay) is at least in part secondary to an interference due to the relative increase in FFA levels (23). Nonetheless, it is worth noting that sustained exposure to $\beta$-adrenergic stimulation generates an increase in serum $\mathrm{T}_{3}$ levels (24), in keeping with an activation of the type- 2 deiodinase-mediated $\mathrm{T}_{4}$ to $\mathrm{T}_{3}$ conversion $(25,26)$. It is thus conceivable that prolonged exposure to mild cold temperature will result in a significant activation of the thyroid axis (with a further increase in $\mathrm{EE}$ ) as a long-term compensatory response to cold exposure. Finally, although no changes were demonstrated in the ACTH levels, the small but significant increase in urinary free cortisol (and serum cortisol in men) implies activation of the hypothalamicpituitary-adrenal axis consistent with a stress response. The changes in the glucocorticoid and thyroid axes were particularly evident in males. Although we cannot rule out gender as a primary cause of these differences, it is possible that the observed changes are at least in part attributable to the higher proportion of fat-free mass in males. Conversely, the greater increase in urinary cortisol observed in females is probably related to the lower fat-free mass (and hence relatively lower urinary creatinine), since the excretion was measured as cortisol/creatinine ratio. 
Our data indicate that subtle modulations in the environmental temperature, well within the limits of tolerability, result in significant changes in $\mathrm{EE}$ and in many hormonal axes. The magnitude of the observed increase in EE is remarkable, since it is similar or superior to pharmacological interventions aimed at increasing EE and ultimately to weight loss (27-30). Indeed, projecting the point estimate increase in EE from this study over the 24 -h period would represent $20 \%$ of the negative energy balance commonly prescribed in weight loss interventions $(31,32)$. It is worth noting that the strict adherence to such regimens is uncommon, and that the self-assessment of the dietary intake is usually biased toward under-reporting (33); hence the actual deficit in energy balance required to achieve a sustained weight loss would probably be significantly less than what is commonly prescribed, remarkably similar to the one we observed (2).

It is possible that compensatory mechanisms, such as an increase in energy intake (appetite), would prevent weight loss (34). Furthermore, our data indicate that exposure to $19^{\circ} \mathrm{C}$ leads to a mild increase in blood pressure, a state of relative insulin resistance, and a marginal increase in cortisol whose long-term consequences could potentially trump the beneficial effects of increasing resting EE.

This study is a proof-of-concept that manipulations in the environmental temperature, well within the range of tolerability, result in a significant increase in $\mathrm{EE}$ and in measurable changes in hormonal homeostasis. One plausible mechanism is catecholamine induction of brown adipose tissue (BAT)-like activity. While no changes were observed in the BAT-specific transcripts in the subcutaneous adipose tissue, it is possible that longer duration of exposure to $19{ }^{\circ} \mathrm{C}$ could stimulate transcription of BAT-specific genes $(35,36)$. However, the actual contribution of BAT to the maintenance of energy balance in humans has not been empirically demonstrated, and it is possible that other tissues such as skeletal muscle may play a major role in adaptive thermogenesis in adult humans (37).

The findings of this study are particularly robust since, to the best of our knowledge, this is the first to study the simultaneous characterization of the changes in EE, sympathetic nervous system activity, and hormonal axes by frequent blood sampling in response to minimal perturbations of the environmental temperature in a relatively large number of volunteers of both the sexes. The study design and the use of a diet-controlled run-in period virtually eliminate the possibility of bias due to carry-over effect, and any confounder due to anticipation. Furthermore, we carefully calibrated our whole room indirect calorimeters at each temperature to ensure accurate measurements of physiological changes in EE and substrate oxidation. One obvious limitation of the study is represented by the brevity of the intervention; we were thus unable to demonstrate any difference in clinically significant endpoints, such as BMI, body composition, and carbohydrate metabolism parameters. Furthermore, we could not evaluate the effects of counter-regulatory mechanisms. Since our study population was limited to non-obese, relatively young individuals, it is also possible that subjects with a higher percentage of fat mass, such as overweight and elderly individuals, may have a blunted response to this intervention (38). When we explored the individual changes in EE with respect to fat mass and changes in plasma norepinephrine, we observed a non-significant negative trend that supports this hypothesis (data not shown). Although we performed multiple comparisons on our dataset, one should consider that the primary endpoint was defined $a$ priori in the setting of the statistical power analysis and that the findings in the various secondary endpoints are in keeping with the study hypothesis and primary endpoint findings. Thus, the possibility of type-1 error appears extremely unlikely.

In conclusion, our study demonstrates that minimal modulation in the environmental temperature results in a significant and potentially clinically relevant increase in EE. Further studies are needed to investigate the longterm effects of mild cold exposure on clinically relevant end-points and its applicability as an intervention aimed to promote weight loss.

\section{Declaration of interest}

The authors declare that there is no conflict of interest that could be perceived as prejudicing the impartiality of the research reported.

\section{Funding}

This work was supported by the Intramural Research Program of the NIDDK programs Z01-DK047057-02, Z01-DK071013-02, and the Clinical Center, NIH.

\section{Acknowledgements}

The authors gratefully acknowledge the help and professionalism of the nursing, laboratory, and ancillary personnel of the NIH Clinical Center. This research could have not been accomplished without the selfless participation of the study volunteers. The authors are grateful to Megan P Rothney, Jennifer Jang, Ornella Dubaz, and Javier Luzon for their technical contributions and Dr Phillip Gorden for his invaluable encouragement, comments, and suggestions.

\section{References}

1 Popkin BM, Kim S, Rusev ER, Du S \& Zizza C. Measuring the full economic costs of diet, physical activity and obesity-related chronic diseases. Obesity Reviews 20067 271-293. (doi:10. 1111/j.1467-789X.2006.00230.x)

2 Hill JO, Wyatt HR, Reed GW \& Peters JC. Obesity and the environment: where do we go from here? Science 2003299 853-855. (doi:10.1126/science.1079857)

3 Ravussin E, Lillioja S, Anderson TE, Christin L \& Bogardus C. Determinants of 24-hour energy expenditure in man. Methods and results using a respiratory chamber. Journal of Clinical Investigation 198678 1568-1578. (doi:10.1172/JCI112749) 
4 Magnus-Levy A. Uber den respiratorischen gaswechsel unter dem einfluss der thyroidea sowie unter verschiedenen pathalogischen zustanden. Berliner Klinische Wochenschrift $18953 \mathbf{4}$ 650-652.

5 Astrup A. Thermogenic drugs as a strategy for treatment of obesity. Endocrine 200013 207-212. (doi:10.1385/ENDO:13:2: 207)

6 van Marken Lichtenbelt WD, Schrauwen P, van De Kerckhove S \& Westerterp-Plantenga MS. Individual variation in body temperature and energy expenditure in response to mild cold. American Journal of Physiology. Endocrinology and Metabolism 2002282 E1077-E1083. (doi:10.1152/ajpendo.00020.2001)

7 van Marken Lichtenbelt WD, Vanhommerig JW, Smulders NM, Drossaerts JMAFL, Kemerink GJ, Bouvy ND, Schrauwen P \& Teule GJJ. Cold-activated brown adipose tissue in healthy men. New England Journal of Medicine 2009360 1500-1508. (doi:10. 1056/NEJMoa0808718)

8 Virtanen KA, Lidell ME, Orava J, Heglind M, Westergren R, Niemi T, Taittonen M, Laine J, Savisto N-J, Enerback S \& Nuutila P. Functional brown adipose tissue in healthy adults. New England Journal of Medicine $2009 \mathbf{3 6 0}$ 1518-1525. (doi:10.1056/ NEJMoa0808949)

9 Cypess AM, Lehman S, Williams G, Tal I, Rodman D, Goldfine AB, Kuo FC, Palmer EL, Tseng Y-H, Doria A, Kolodny GM \& Kahn CR. Identification and importance of brown adipose tissue in adult humans. New England Journal of Medicine 2009360 1509-1517. (doi:10.1056/NEJMoa0810780)

10 McAllister EJ, Dhurandhar NV, Keith SW, Aronne LJ, Barger J, Baskin M, Benca RM, Biggio J, Boggiano MM, Eisenmann JC, Elobeid M, Fontaine KR, Gluckman P, Hanlon EC, Katzmarzyk P, Pietrobelli A, Redden DT, Ruden DM, Wang C, Waterland RA, Wright SM \& Allison DB. Ten putative contributors to the obesity epidemic. Critical Reviews in Food Science and Nutrition 200949 868-913. (doi:10.1080/10408390903372599)

11 Mifflin MD, St Jeor ST, Hill LA, Scott BJ, Daugherty SA \& Koh YO. A new predictive equation for resting energy expenditure in healthy individuals. American Journal of Clinical Nutrition $1990 \mathbf{5 1}$ 241-247.

12 The Dietary Reference Intakes: The Essential Guide to Nutrient Requirements, pp 84. Eds JPH Jennifer, J Otten \& LD Meyers. Washington, DC: National Academies Press, 2006.

13 de Jonge L, Nguyen T, Smith SR, Zachwieja JJ, Roy HJ \& Bray GA. Prediction of energy expenditure in a whole body indirect calorimeter at both low and high levels of physical activity. International Journal of Obesity and Related Metabolic Disorders 200125 929-934. (doi:10.1038/sj.ijo.0801656)

14 Smith SR, de Jonge L, Zachwieja JJ, Roy H, Nguyen T, Rood JC, Windhauser MM \& Bray GA. Fat and carbohydrate balances during adaptation to a high-fat. American Journal of Clinical Nutrition 200071 450-457.

15 Hull H, He Q, Thornton J, Javed F, Allen L, Wang J, Pierson RN Jr \& Gallagher D. iDXA, prodigy, and DPXL dual-energy X-ray absorptiometry whole-body scans: a cross-calibration study. Journal of Clinical Densitometry 200912 95-102. (doi:10. 1016/j.jocd.2008.09.004)

16 Kinugasa H \& Hirayanagi K. Effects of skin surface cooling and heating on autonomic nervous activity and baroreflex sensitivity in humans. Experimental Physiology 199984 369-377. (doi:10. 1017/S0958067099018394)

17 Task Force of the European Society of Cardiology and the North American Society of Pacing and Electrophysiology. Heart rate variability: standards of measurement, physiological interpretation and clinical use. Circulation 199693 1043-1065.

18 Eisenhofer G, Goldstein DS, Stull R, Keiser HR, Sunderland T, Murphy DL \& Kopin IJ. Simultaneous liquid-chromatographic determination of 3,4-dihydroxyphenylglycol, catecholamines, and 3,4-dihydroxyphenylalanine in plasma, and their responses to inhibition of monoamine oxidase. Clinical Chemistry 198632 2030-2033.
19 Dauncey MJ. Influence of mild cold on $24 \mathrm{~h}$ energy expenditure, resting metabolism and diet-induced thermogenesis. British Journal of Nutrition $1981 \quad \mathbf{4 5}$ 257-267. (doi:10.1079/ BJN19810102)

20 Westerterp-Plantenga MS, van Marken Lichtenbelt WD, Strobbe H \& Schrauwen P. Energy metabolism in humans at a lowered ambient temperature. European Journal of Clinical Nutrition 2002 56 288-296. (doi:10.1038/sj.ejcn.1601308)

21 Fagius J \& Kay R. Low ambient temperature increases baroreflexgoverned sympathetic outflow to muscle vessels in humans. Acta Physiologica Scandinavica 1991142 201-209. (doi:10.1111/j. 1748-1716.1991.tb09148.x)

22 Rizza RA, Cryer PE, Haymond MW \& Gerich JE. Adrenergic mechanisms for the effects of epinephrine on glucose production and clearance in man. Journal of Clinical Investigation $1980 \mathbf{6 5}$ 682-689. (doi:10.1172/JCI109714)

23 Csako G, Zweig MH, Ruddel M, Glickman J \& Kestner J. Direct and indirect techniques for free thyroxine compared in patients with nonthyroidal illness. III. Analysis of interference variables by stepwise regression. Clinical Chemistry 199036 645-650.

24 Scheidegger K, O'Connell M, Robbins DC \& Danforth E Jr. Effects of chronic $\beta$-receptor stimulation on sympathetic nervous system activity, energy expenditure, and thyroid hormones. Journal of Clinical Endocrinology and Metabolism 198458 895-903. (doi:10. 1210/jcem-58-5-895)

25 Maia AL, Kim BW, Huang SA, Harney JW \& Larsen PR. Type 2 iodothyronine deiodinase is the major source of plasma $\mathrm{T}_{3}$ in euthyroid humans. Journal of Clinical Investigation $2005 \mathbf{1 1 5}$ 2524-2533. (doi:10.1172/JCI25083)

26 Canettieri G, Celi FS, Baccheschi G, Salvatori L, Andreoli M \& Centanni M. Isolation of human type 2 deiodinase gene promoter and characterization of a functional cyclic adenosine monophosphate response element. Endocrinology $2000 \mathbf{1 4 1}$ 1804-1813. (doi:10.1210/en.141.5.1804)

27 Bracco D, Ferrarra JM, Arnaud MJ, Jequier E \& Schutz Y. Effects of caffeine on energy metabolism, heart rate, and methylxanthine metabolism in lean and obese women. American Journal of Physiology 1995269 E671-E678.

28 Hansen DL, Toubro S, Stock MJ, Macdonald IA \& Astrup A. Thermogenic effects of sibutramine in humans. American Journal of Clinical Nutrition 199868 1180-1186.

29 Shannon JR, Gottesdiener K, Jordan J, Chen K, Flattery S, Larson PJ, Candelore MR, Gertz B, Robertson D \& Sun M. Acute effect of ephedrine on 24-h energy balance. Clinical Science 1999 96 483-491. (doi:10.1042/CS19980206)

30 Yoshioka M, Doucet E, Drapeau V, Dionne I \& Tremblay A. Combined effects of red pepper and caffeine consumption on $24 \mathrm{~h}$ energy balance in subjects given free access to foods. British Journal of Nutrition $2001 \quad 85$ 203-211. (doi:10.1079/ BJN2000224)

31 Sacks FM, Bray GA, Carey VJ, Smith SR, Ryan DH, Anton SD, McManus K, Champagne CM, Bishop LM, Laranjo N, Leboff MS, Rood JC, de Jonge L, Greenway FL, Loria CM, Obarzanek E \& Williamson DA. Comparison of weight-loss diets with different compositions of fat, protein, and carbohydrates. New England Journal of Medicine $2009 \mathbf{3 6 0} 859-873 . \quad$ (doi:10.1056/ NEJMoa0804748)

32 The Practical Guide: Identification, Evaluation, and Treatment of Overweight and Obesity in Adults, P 19. NIH Publication Number 00-4084, 2000.

33 Westerterp KR \& Goris AH. Validity of the assessment of dietary intake: problems of misreporting. Current Opinion in Clinical Nutrition and Metabolic Care 20025 489-493. (doi:10.1097/ 00075197-200209000-00006)

34 Vander A, Sherman J \& Luciano D. Regulation of organic metabolism, growth, and energy balance. In Human Physiology. The Mechanism of Body Function, 7th edn, pp 625-633. Boston, MA: WCB/McGraw-Hill, 1998.

35 Skarulis MC, Celi FS, Mueller E, Zemskova M, Malek R, Hugendubler L, Cochran C, Solomon J, Chen C \& Gorden P. Thyroid hormone induced brown adipose tissue and amelioration 
of diabetes in a patient with extreme insulin resistance. Journal of Clinical Endocrinology and Metabolism 200995 256-262. (doi:10. 1210/jc.2009-0543)

36 Huttunen P, Hirvonen J \& Kinnula V. The occurrence of brown adipose tissue in outdoor workers. European Journal of Applied Physiology and Occupational Physiology 198146 339-345. (doi:10.1007/BF00422121)

37 Schrauwen P, Westerterp-Plantenga MS, Kornips E, Schaart G \& van Marken Lichtenbelt WD. The effect of mild cold exposure on UCP3 mRNA expression and UCP3 protein content in humans. International Journal of Obesity and Related Metabolic Disorders 200226 450-457. (doi:10.1038/sj.ijo. 0801943)

38 Wijers SL, Saris WH \& van Marken Lichtenbelt WD. Coldinduced adaptive thermogenesis in lean and obese. Obesity 2010 18 1092-1099. (doi:10.1038/oby.2010.74)

Received 20 August 2010

Accepted 7 September 2010 